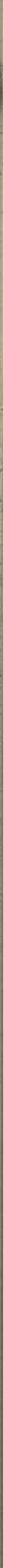

I D P HID PHD RUS IMP $\mathbb{P} \mathbb{Y} A \mathbb{N} U S$.

Female. $\%$. Natisize. 
TABb. LX. ET LXI.

\section{LOPHOPHORUS IMPEYANUS.}

IT is not a little singular that the elevated regions of the Himalaya, verging upon the limits of perpetual snow, should present us with a tribe of birds which are distinguished almost beyond all others by the brilliancy of their plumage ;-we allude to an extensive group of the family of Phasianida, forming several genera, among which the genus before us is pre-eminently characterized by the intense metallic lustre of its colours. The genus Lophophorus, first established by the illustrious Cuvier, is very limited in its numbers, the present splendid bird being the only species now acknowledged as having true claim to the generic title.

That a bird, which if introduced into our country would form a splendid ornament to our woods and lawns, and which would doubtless bear the climate as well as the Peacock from the plains of India, or the Pheasant of the confines of China, should have been hitherto almost a stranger even to our museums, is a circumstance to be wondered at, and only to be attributed to the remoteness of its native habitat, and the difficulty of transporting it across a wide extent of country before it can reach the coast. We may hope, however, that by the exertions of our numerous scientific investigators of India it may ere long become a denizen of our parks.

The food of the Impeyan Pheasant consists in a great measure of bulbous roots, for the scooping up of which the upper mandible, like that of the Francolins, being of a spoonlike form, is peculiarly adapted.

Nothing can present a stronger contrast than the plumage of the female and young male with that of the adult male. While in the latter all is resplendent with tints of burnished green and purple changing in every light, in the former the general colour is of a deep brown variegated with lines of white and zigzag markings of rusty brown, a colour with which the feathers of the tail are barred. The crest of such birds merely consists of somewhat lengthened feathers.

In the adult male, the head is ornamented with a crest of long feathers, each of which arises by a slender filiform peduncle and becomes spatulate at its extremity. This crest as well as the head and throat are of a rich metallic green; the back of the neck of a metallic purple; the back and wings are steel blue, a white bar crossing the middle of the former; the tail is rich ferruginous deepening at the extremity; the whole of the under surface black.

Tab. LX. represents the male, and Tab. LXI. the female, two thirds of their natural size. 


\section{$2 \mathrm{BHL}$ Biodiversity Heritage Library}

Gould, John. 1831. "Lophophorus impeyanus [Tab. LXI]." A century of birds from the Himalaya Mountains -. https://doi.org/10.5962/p.323527.

View This Item Online: https://www.biodiversitylibrary.org/item/132967

DOI: https://doi.org/10.5962/p.323527

Permalink: https://www.biodiversitylibrary.org/partpdf/323527

\section{Holding Institution}

Smithsonian Libraries

\section{Sponsored by}

Biodiversity Heritage Library

\section{Copyright \& Reuse}

Copyright Status: Public domain. The BHL considers that this work is no longer under copyright protection.

This document was created from content at the Biodiversity Heritage Library, the world's largest open access digital library for biodiversity literature and archives. Visit BHL at https://www.biodiversitylibrary.org. 